Meta

Journal des traducteurs

Translators' Journal

\title{
The Happy Adventure of Translating German Humorous Verse
}

\section{Max Knight}

Volume 37, numéro 3, septembre 1992

URI : https://id.erudit.org/iderudit/003328ar

DOI : https://doi.org/10.7202/003328ar

Aller au sommaire du numéro

Éditeur(s)

Les Presses de l'Université de Montréal

ISSN

0026-0452 (imprimé)

1492-1421 (numérique)

Découvrir la revue

Citer cet article

Knight, M. (1992). The Happy Adventure of Translating German Humorous Verse. Meta, 37(3), 474-481. https://doi.org/10.7202/003328ar

\section{Résumé de l'article}

L'auteur parle du plaisir qu'on peut éprouver à traduire de la poésie. Il exprime la satisfaction qu'il y a à trouver des rimes aussi évocatrices que celles du poème original. Il traite ensuite de l'importance, dans la traduction poétique, du bon découpage des unités de traduction et donne des exemples de traductions poétiques qui demandent différents découpages. Les problèmes touchant la traduction de dialectes sont également traités, et l'article se termine sur des réflexions concernant l'opposition éternelle entre traduction fidèle et traduction libre.
Ce document est protégé par la loi sur le droit d'auteur. L'utilisation des services d'Érudit (y compris la reproduction) est assujettie à sa politique d'utilisation que vous pouvez consulter en ligne.

https://apropos.erudit.org/fr/usagers/politique-dutilisation/ 


\title{
THE HAPPY ADVENTURE OF TRANSLATING GERMAN HUMOROUS VERSE
}

MAX KNIGHT

University of California, Berkeley, California, USA

\begin{abstract}
Résumé
L'auteur parle du plaisir qu'on peut éprouver à traduire de la poésie. Il exprime la satisfaction qu'il y a à trouver des rimes aussi évocatrices que celles du poème original. Il traite ensuite de l'importance, dans la traduction poétique, du bon découpage des unités de traduction et donne des exemples de traductions poétiques qui demandent différents découpages. Les problèmes touchant la traduction de dialectes sont également traités, et $l$ l'article se termine sur des réflexions concernant l'opposition éternelle entre traduction fidèle et traduction libre.
\end{abstract}

Der Lattenzaun

Es war einmal ein Lattenzaun, mit Zwischenraum, hindurchzuschaun.

Ein Architekt, der dieses sah, stand eines Abends plötzlich da-

und nahm den Zwischenraum heraus und baute draus ein großes Haus.

Der Zaun indessen stand ganz dumm, mit Latten ohne was herum.

Ein Anblick gräßlich und gemein. Drum zog inn der Senat auch ein.

Der Architekt jedoch entfloh nach Afri-od-Ameriko.
The Picket Fence

There used to be a picket fence with space to gaze from hence to thence

An architect who saw this sight approached it suddenly one night,

removed the spaces from the fence, and built of them a residence.

The picket fence stood there dumbfounded with pickets wholly unsurrounded,

a view so naked and obscene, the sheriff had to intervene.

The architect absconded, though, to Afri- or Americo.

In German-speaking countries these verses by Christian Morgenstern are as familiar as Mother Goose here. But in the English-speaking orbit they are not - at least they were not until recently, when they were published in translation. I have been fond of them since I grew up as a boy in Austria, but when I came to this country and wanted to share this poem and the others by Morgenstern, collected in his volume Galgenlieder, with my American friends, I found no translation in the library. Even the name of the author drew a blank with my friends. So I looked up a copy of Cassell's Encyclopedia of World Literature - that was back in 1954 - and under the entry Christian Morgenstern I read:

"German poet, 1871 to 1914 . He ranks very high among modern German poets, but his international reputation is severely handicapped by the fact that many of his best works are practically untranslatable." 
And then I looked up the Anthology of German Poetry by Angel Flores, and found:

"Morgenstern's parodies, punning, and satiric truculence succeeded in creating an Alice-inWonderland climate, which endeared him to millions of readers throughout the Germanspeaking world, but which, of course, defies translation."

I relished these lines, especially the delicious "of course": "which of course, defies translation." It was a challenge.

This personal background of the translation of the Galgenlieder published by the University of California Press provides the answer to why it is such a happy adventure to translate German humorous verse: the wish to share (which is the source of all translation, not just verse), and the challenge to try something considered difficult.

Once I found a statement in that ultimate source of wisdom, a Chinese fortune cookie. It said: "The great pleasure in life is doing what people say you cannot do."

\section{UNIT IS THE WORD}

I trust you will be charitable enough to share my unsophisticated pleasure in stealing a march on the encyclopedia when the translation made the front page of the Times Literary Supplement in London, the New York Times, and the literary journals.

But, then, why all the fuss? What's so difficult about translating the "Picket Fence" - beyond, perhaps, rhyming? Translating this poem is indeed no more difficult than translating any rhymed poetry. The "Picket Fence" permits an almost mirror-like word-for-word rendering of the original. The unit of translation is the individual word:

Er nahm den $Z$ wischenraum heraus und baute draus ein grosses Haus. ...removed the spaces from the fence, and built of them a residence.

\section{UNIT IS THE IDIOM OR PUN}

But the unit of translation cannot always be the word. Every language has idioms that would be meaningless if translated literally, hence the unit has to be the entire idiom. There is a German idiom for somebody giving up in disappointment; translated literally, he is said "to toss a rifle in the wheat field" - whatever the origin of that phrase might be. Now Morgenstern, taking the idiom literally, tells of a man who walks in a wheat field, finds a rifle, and mournfully reflects on the hopeless poor devil who cast away the rifle. If the poem were translated word for word into English, it would make no sense. This now is a challenge. Here the happy hunt begins for the translator to find an idiom that could convey the same idea. There is one. If you translate the German word for rifle by "towel," the meaning clicks: Somebody finds a towel and is sorry for the discouraged loser who has thrown it in.

Finding an equivalent that fits is as exciting for a translator as finding a word that fits is for the crossword-puzzle fan.

Related to the idiom, from the translator's standpoint, are the plays on words, the puns, that are accidents of language. (And, before continuing, let me say a kind word for the pun. The word seems to elicit a knee-jerk reaction as low-level crude humor. As a generalization, this is unjust and unjustified. A pun can be as subtle as it can be crude it depends on the punster.)

Here is an example of translating a pun: 


\section{Das Gebet}

Die Rehlein beten zur Nacht, hab acht!

Halb neun!

Halb zehn!

Halb elf!

Halb zwölf!

Zwölf!

Die Rehlein beten zur Nacht, hab acht!

Sie falten die kleinen Zehlein, die Rehlein.

The task was to find a substitute or at least an approach for the daring jump from hab acht to halb neun. The solution chosen was to use the syllable "-ate" (as in navigate, speculate, congregate) as if it were spelled like the figure 8 .

The Does' Prayer

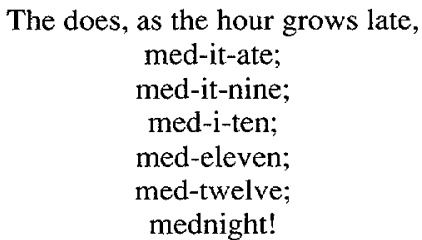

The does, as the hour grows late, medidate.

They fold their little toesies, the doesies.

I cannot resist including a French example here, simply because it is so good. The renowned question "Is life worth living?" and the answer "It depends on the liver" have been beautifully translated as "La vie vaut-elle la peine?" and "Question de foie." (I do not know the name of the translator. The passage is quoted by Leonard Forster in Aspects of Translation, published 1958 in London.)

Karl Kraus, the Austrian essayist, satirist, and critic, was a master in using plays on words. Here is a tender poem in which he uses a multiple pun, based on the German word Fehler. In the first stanza he says that his beloved has some physical imperfection, but it is this very flaw that endears her to him. And then, in the last stanza:

Doch träte selbst die Schönste vor mich hin,

und fehlerlos,

ich wäre meines Drangs zu dir kein Hehler.

Ihr, die so vieles hat, fehlt eines bloss

und alles drum — ach wie vermiss' ich ihn -

ihr fehlt doch, Liebste, was mir fehlt: dein Fehler!

The three German words in the last line have the same sound but three different meanings: "ihr fehlt": she lacks; "was mir fehlt": what I miss; "dein Fehler": your shortcoming, flaw, imperfection. Still, they can be reconciled in translation: 
Yet if there came the fairest of the fair, and flawless she, my thoughts of you would linger and keep haunting.

No matter what her charms and virtues be, her fault would be the flaw that wasn't there -

I would not want her if your want were wanting.

Here is yet another example of the accidental word-sound challenge. The first part of the word for elephant in German is similar to the number eleven - vaguely similar even in English. Thus, Morgenstern, in a poem he called "Ant-ology" - spelled without $h$ - constructs an evolutionary ladder of numbers. He begins with the German word Gig-ant (English, giant), which, he says, is a very large number, then descends the ladder in German, making up a word Zwölefant, then Elefant. Here we can duplicate the pun. We can also begin with a large imaginary number called "gi" (after all, there is a number called "pi") and can form from gi the creature "gi-ant"; we then descend, as in German, to "tweleph-ant" and "eleph-ant," only to stumble, lo and happy behold, onto "ten-ant," a bonus. Finally we reach another bonus, the "ant," indeed a tiny figure at the bottom of the ladder that began with the gi-ant. Where German has a triple pun - Gigant, Zwölefant, Elefant - English permits a quintuple pun - giant, twelephant, elephant, tenant, ant.

Anto-logie

Im Anfang lebte, wie bekannt, als größter Säuger der Gig-ant.

Wobei gig eine Zahl ist, die es nicht mehr gibt, - so groß war sie!

Doch jene Größe schwand wie Rauch. Zeit gab's genug, - und Zahlen auch.

Bis eines Tags, ein winzig Ding, der Zwölef-ant das Reich empfing.

Wo blieb sein Reich? Wo blieb er selb? Sein Bein wird im Museum gelb.

Zwar gab die gütige Natur den Elef-anten uns dafur.

Doch ach, der Pulverpavian, der Mensch voll Gier nach seinem Zahn, erschießt ihn, statt ihm Zeit zu lassen, zum Zehen-anten zu verblassen.

$O$ "Klub zum Schutz der wilden Tiere", hilf, daß der Mensch nicht ruiniere

die Sprossen dieser Riesenleiter, die stets noch weiter führt und weiter!

Wie dankbar wird der Ant dir sein, läßt du ihn wachsen und gedeihn, -

bis er dereinst im Nebel hinten als Nulel-ant wird stumm verschwinden.
Anto-logy

Of yore, on earth was dominant the biggest mammal: the Gig-ant

("Gig" is a numeral so vast, it's been extinct for ages past.)

But off, like smoke, that vastness flew. Time did abound, and numbers too.

until one day a tiny thing, the Tweleph-ant, was chosen king.

Where is he now? Where is his throne? In the museum pales his bone.

True, Mother Nature gave with grace the Eleph-ant us in his place,

but, woe, that shooting anthropoid called "Man," in quest for tusks destroyed

him ere he could degenerate by stages, to an Ten-ant's state.

O noble club, SPCA, don't let Man wholly take away

the steps of that titanic scale that leads still farther down the trail.

How grateful will the Ant survive if left to flourish and to thrive,

until he, in a far-off year, as Zero-ant will disappear. 
The translation unit, then, can be larger than the word. It can be an idiom (throw in the towel) or it can be a pun (ten-ant, meditate, Fehler, la foi) that requires adjustments going beyond translation of one word.

\section{UNIT IS THE IDEA}

But the translation unit can be larger still. It may be the entire poem, the idea. When Johann Nestroy wrote his Austrian comedies, he inserted songs (couplets) of three or four stanzas with a recurring refrain such as: "People don't know what they want," or "How lucky that different people are different," or "Look how people pretend." He then used the stanzas to illustrate these chorus lines with examples. His examples are mostly out-dated now, and a literal translation would fall flat. This is particularly true of the encore stanza, in which Nestroy illustrated his final line by a current event, often a political episode of his day. In translating the plays of Nestroy, I felt free to write entirely new stanzas, retaining only the chorus line in each. For example, one stanza begins, in anachronistic translation, with the words:

They now have a bomb that more damage can do

than all bombs together in World War II.

\section{Nestroy died in 1860 .}

Such treatment goes beyond translation. But it is an integral part of the translator's work. This kind of updating has been done by the producers of all stage productions since Nestroy's death - in fact, it was done by Nestroy himself, who wrote last-minute encore stanzas for his productions alluding to events that may have been no older than a few days, and invariably brought down the house. The translator's task here is to aim at creating a reaction in the audience similar to that produced by the original - even if the words are entirely different.

\section{DIALECT}

There is yet another dimension, going beyond the one-word unit, the multiword unit, and the entire piece to be translated - the problem of slang or dialect. How can one translate slang or dialect? Nestroy wrote his comedies in Viennese dialect. They were deeply rooted in the Vienna scene of the second half of the nineteenth century. Nestroy was not translated, although, to this day, he is the most-played comedy writer in the German tongue - if, indeed, you accept Viennese as German. Nestroy was not even translated into standard German until after World War II. The slang could not be translated. Thornton Wilder adapted one of Nestroy's plays into The Merchant of Yonkers, which became The Matchmaker, which further was transformed into the world success of Hello Dolly. My friend, Mr.Joseph Fabry, and I, inspired by Wilder, tried our hands, translated three plays, and sent the manuscript to him for criticism. Here, in part, is his handwritten answer:

Many thanks for translating the Nestroy plays and letting me see them. But - God in Heaven - how can you be both such good and such bad translators?... The element I thought you'd be worst, you do best - the couplets. Where you fall flat on your faces is in your use of contemporary American slang.... "[Slang expressions transferred to] another country, another epoch, stick out like sore thumbs, they loudly call attention to themselves.

\section{Thornton Wilder continued:}

"But, Mr.Wilder", you will say, "Nestroy's low-life characters do talk constant and vivid slang. How can we translate that truth and that force?" 
By art. By skill. By invention. By substitution. That's your job. Give all the feeling of working-class character anywhere without planting their talk in England or America. You are very good translators, except for this blind spot...

So, what is he saying? If a character is, for example, a lowly cobbler, let him use words that are germane to a lowly cobbler, let him use language that characterizes his social position without placing him in any particular country. Mr.Wilder, in the same letter, cited examples from our manuscript of what not to use because of its typical American cast: "pooped," "vinegar puss," "my doll."

Needless to say, we combed our translation carefully for Americanisms, and Mr. Wilder was pacified enough to write the foreword for the book.

But only a few days ago I received a volume, Anthology of Modern Austrian Literature published under the auspices of the International P.E.N. Club by Oswald Wolff in London, which presents Austrian poets and writers in English translation. It includes such arch-Viennese slang writers as Helmut Qualtinger and makes him speak London cockney slang - an absolute absurdity, as we realize now after Mr. Wilder opened our eyes.

FAITHFUL OR FREE

The translations of the Nestroy couplets, then, were not "faithful," yet Thornton Wilder approved. Few translators escape the charge of being unfaithful, but the choice between translating freely or faithfully usually does not depend on the translator but on the nature of the original. The "Picket Fence" could be translated faithfully, the "Doe's Prayer" could not. The pleasure of translating, however, inheres in both approaches. See how beautifully the rhymes and meter click in this more or less literal translation of lines by Wilhelm Busch, done beautifully by Walter Arndt of Dartmouth College, describing the arrival of a newly born to Painter Klecksel:

Früh zeigt er seine Energie,

indem er ausdermassen schrie;

Denn früh belehrt ihn die Erfahrung:

Sobald er schrie, bekam er Nahrung.
He is robust, as one can tell

by his all-penetrating yell;

Experience led him to conclude:

Persistent yells result in food.

There is not a word too much or to little, and nothing is twisted to fit the meter or rhyme. The pleasure, the satisfaction, comes from the naturalness of the lines, from the unforced pitter-patter. The danger of artificial twisting is strong in translating German verse. German word order invites inversions, which are usually unacceptable in English. Compare the just-quoted lines with the following, from a different translation (Max Born) published some years ago:

For soon him shows experiment

That screaming leads to nourishment.

(In parenthesis: The craftsmanship in forging verses shows when every word is exactly in the place where it would be if it were said in prose. Here are four lines by the master Ogden Nash, so liquid and natural that you would not say them otherwise if you had never heard of meter and rhyme:

One of the things that I've tried quite hard but still haven't managed to cope with, is the cake of soap that's too thick to discard but a little too thin to soap with.

End of digression.) 
The successful literal translation, then, is a pleasure to the translator and the reader. On the other hand, the free translation (as in the earlier examples) has its own rewards. It allows the translator great creativeness. Although he is bound by the words and ideas of the original, his work is highly personal. He can choose from many alternatives and interpretations, which make his version as revealing as a Rorschach test. A translation, like handwriting, shows the character of the translator.

When it comes to the charge of unfaithfulness, the translator of verse is in double jeopardy. In addition to translating the words, he has to recreate the meter and rhyme schemes, and it is there where his creativeness has an opportunity. A business letter can be translated by a businessman. A poem has to be translated by a poet.

Over the centuries and in all languages, keen observations have been made about the art of translating - applying to both prose and verse.

A Hebrew teacher of the first century, Jehuda ben Ilai, talking about translating the Bible, said that literal translating means lying, and free translating means blaspheming.

There is the much-quoted French saying that translations are like women: "If they are beautiful, they are not faithful, and if they are faithful, they are not beautiful," matched by the equally well-known Spanish saying (credited to Cervantes) that "translating from one language to another is like gazing at a Flemish tapestry with the wrong side out."

There is, of course, the classic Italian verdict, unhearable in its succinctness: "Traduttore, traditore" - translator, traitor, a pun in itself untranslatable with equal pungency. And to include one American quotation in this United Nations of condemnation: John Ciardi in the Saturday Review of Literature has called translation flatly "the art of failure."

Yes, yes, true, true - they all are right. But even John Ciardi gives us a chance. He says: "What a translator tries for is no more than the best possible failure." So we will at least have the challenge of aiming at a good failure.

But this is not the last word. The worm can turn. There may be instances when a good translation, far from being inferior to the original, may be superior to it. A provocative statement. But a good translator works in a double capacity - as translator and as editor. He looks at the original with more searching eyes than most readers. He has to plumb the depth of the meaning of every word.

Karl Kraus wrote a poem about a park surrounding a Bohemian castle. It seemed a rather formal park, perhaps somewhat like Versailles, with a pond and swan, with flowerbeds, and possibly statuary - the latter because one line says: "Wie lange steht er schon auf diesem Stein, der Admiral," literally: "How long has the admiral been standing on this stone." Apparently there was a statue of a navy warrior in that park. I translated accordingly — but it didn't seem quite right. It occurred to me that there is a butterfly called admiral. On a hunch I did some research, wrote to Czechoslovakia, and learned there is no statuary in that park and never was. So Kraus must indeed have meant the butterfly. (The preceding line in Kraus's poem actually speaks about flowers.) Since intended ambiguity for the benefit of the reader's imagination could not have been assumed in this context, I changed my translation of the word "admiral" from "admiral" to "butterfly" and of the word "standing" (which Kraus evidently used in poetic license to indicate the folded vertical wings) as "sitting": "Upon the rock is sitting the butterfly." Such interpretive translating I hoped would make the poem more understandable to foreign readers not familiar with the park.

Because of this "posthumous," as it were, cleaning up of over-looked flaws, Roda Roda, the Austro-Hungarian writer of the First World War, in direct opposition to John Ciardi, said: "A translation is good only when it is better than the original." Paul Valéry, Roda's French contemporary, made a similar statement. 
Ordinarily, though, the chicken will not try to be wiser than the hen. The translator will make the best effort, and aiming at excellence is the joy of the happy adventure of translating. The aim is two-pronged. The one prong is devoted identification with the original author - the translator is the alter ego of the author. The other prong is the creativeness that is the translator's own, highly individual expression. The synthesis of these two divergent aims makes for the finest translation.

In my own work, I thought that at least on one occasion I was close to that synthesis - an occasion where I felt the author was smiling down from the heavens when he saw what was being done to his work, as I was sailing precariously between Ciardi and Roda Roda. Trans-lating, translated literally, means "carrying across" - you carry the text from one side of the linguistic border to the other, visually expressed perhaps by turning over the palm of your hand.

Morgenstern's most celebrated, indeed most eloquent, poem permits that synthesis,

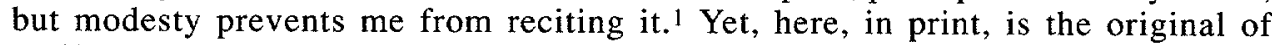
Fish's Nightsong:

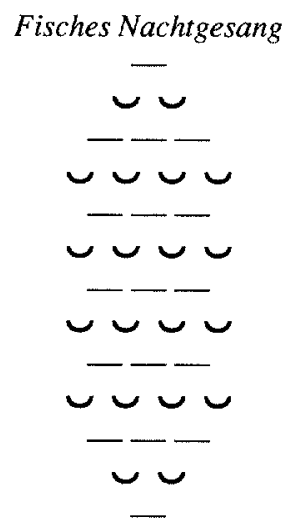

And here is the translation:

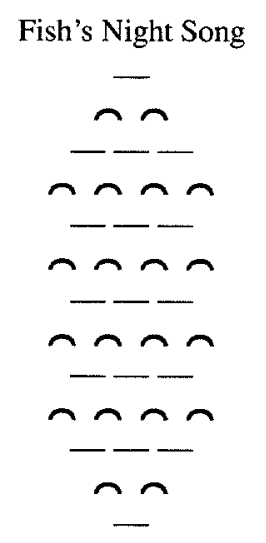

NOTE

1. Originally presented orally at the Humor Conference, University of Arizona, Tempe, April 1982. 